\title{
Review of New Zealand Monetary Policy
}

\section{Arthur Grimes}

$\mathrm{I}$ n May 2000, Professor Lars Svensson was invited by the then newly-elected New Zealand Minister of Finance 'to review the way in which New Zealand's monetary policy is conducted and its effectiveness in contributing to broader social and economic objectives'. The report of the Review was published recently (Svensson, 2001). Professor Svensson, based at the Institute for International Economic Studies, Stockholm University, has published widely on both monetary theory and monetary policy (for recent examples, see Svensson, 1999 and 2000). He had earlier gained a close understanding of New Zealand monetary policy practices while visiting as a Professorial Fellow of Monetary Economics at Victoria University of Wellington in 1997. Professor Svensson received 30 written submissions to the review and discussed relevant issues with Reserve Bank officials, directors and others outside the Bank. Submissions to the review are available at: www.monpolreview.govt.nz.

The review was commissioned ten years after the Reserve Bank of New Zealand Act 1989 came into force. That Act introduced to the world inflation targeting with an explicit Policy Targets Agreement, and introduced central bank independence to New Zealand. Through the course of the subsequent ten years, the legislative framework for New Zealand monetary policy remained essentially unchanged, but monetary policy practice evolved in some notable directions.

One direction which aroused concern in some circles within New Zealand and occasioned comment in Australia and elsewhere, was the adoption of a Monetary Conditions Index (MCI) as an intermediate target by the Reserve Bank of New Zealand (RBNZ) in June 1997. The subsequent behaviour of the exchange rate and interest rates, combined with earlier volatility in monetary and economic variables and combined with continued lacklustre performance of the New Zealand economy relative to Australia and the United States (especially after the Asian financial crisis), led the then opposition Labour Party to promise an enquiry into monetary policy practices if it won the 1999 general election. Although the MCI had been discontinued as a (front-line) monetary policy intermediate target in March 1999 (prior to the election), the new government felt bound by its election pledge to hold the monetary policy review.

The goal of the review was to examine the legislative framework and the practice of monetary policy after ten years 'to ensure that the monetary policy framework and the Reserve Bank's operations within that framework are appropriate to the characteristics of the New Zealand economy and best

Arthur Grimes is Director of the Institute of Policy Studies, Victoria University of Wellington (and formerly of the Reserve Bank of New Zealand). 
international practice' (Svensson, 2001:67). The terms of reference (TOR) required the review to consider:

1. The way in which monetary policy is managed in pursuit of the inflation target.

2. The instruments of monetary policy (including instrument adequacy and whether current instruments are used effectively).

3. The information used by the Reserve Bank in its decision-making.

4. The monetary policy decision-making process (and accountability structures).

5. The co-ordination of monetary policy with other elements of the economic policy framework (including relationship between monetary and prudential policies).

6. The communication of monetary policy.

Svensson reported on each of these matters, with the most far-reaching recommendations relating to decision-making and accountability structures. Considerable analysis of the first three terms of reference was also contained in the report. Subsequent to the report, each of the Treasury, the Reserve Bank, and the Non-Executive Directors' Committee of the Reserve Bank made (publicly released) submissions to the Minister of Finance regarding the review's findings and recommendations. Following consideration of the review plus the three submissions, the Minister of Finance and Opposition Finance Spokesperson agreed a bi-partisan policy response, also outlined below.

The remainder of the article is devoted to a critique of the theoretical frameworks that lie behind Svensson's key findings and a review of their application to the matters raised by the terms of reference and Svensson's key findings. Some of the insights raised in the review are applied to current Australian central bank arrangements, in order to contemplate how a review based on similar approaches - might judge aspects of Reserve Bank of Australia (RBA) performance and governance structures.

\section{Monetary Framework}

The terms of reference require frameworks both to consider issues of monetary policy (TORs 1, 2, 3, 5 and 6) and to consider issues of governance, decisionmaking and accountability (TOR 4). The former is clearly laid out, and is reviewed below. The latter, as discussed further below, is by contrast lacking. In this section, we lay out the monetary framework used by Svensson.

Firstly, it is important to indicate a key 'given' for the review. The TOR explicitly stated that the goal for monetary policy in New Zealand 'directed to the economic objective of achieving and maintaining stability in the general level of prices' was not part of the review. Government had no wish to change this goal, nor lessen the Bank's accountability, or its operational autonomy, in pursuing this goal.

Nevertheless Professor Svensson (2001:8), addressing these issues, stated: 
there is overwhelming international support, based on theory, empirical results and practical experience, for the general view that the optimal monetary policy framework is characterised by (1) a goal of price stability, (2) operational independence of the central bank and (3) clear accountability of the central bank for achieving the goal. The monetary policy setup in New Zealand is a prime example of such a framework and has been a model for monetary policy reform in many other countries.

This finding is consistent with the monetary policy framework which he presents. Svensson starts from the presumption that the ultimate objective of economic policy is 'to guarantee and enhance the citizens' welfare", which includes goals such as 'efficient resource utilisation, full and stable employment, high economic growth, price stability, equitable distribution of wealth and income, regional balance and environmental protection' (p. 11). While these may all be goals of economic policy, it does not follow that they are goals for monetary policy per se. Monetary policy objectives, Svensson notes, must be consistent with the broader economic objectives but must also be limited to goals which can feasibly be obtained via monetary instruments. This approach, based on Tinbergen (1952), is uncontroversial.

The approach means that it is crucial to specify what can be achieved through monetary policy. In turn, this requires a specification of the transmission channels of monetary policy through to goals such as real output and inflation. Svensson discusses these in the context of a central bank (such as the RBNZ and the RBA) which uses a short-term nominal interest rate as its monetary policy instrument. In New Zealand's case, this interest rate is referred to as the Official Cash Rate (OCR). With sticky prices, adjusting the OCR also results in a real short-term interest rate movement in the same direction. Nominal and real long-run interest rates also generally shift in the same direction, as (normally) do nominal and real exchange rates, ceteris paribus.

Given these relationships, Svensson lays out a number of transmission channels of monetary policy to output and inflation:

- $\quad$ direct exchange rate channel to CPI inflation;

- real-interest-rate channel to aggregate demand;

- exchange rate channel to aggregate demand;

- credit channel to aggregate demand.

Each of the first three is conventionally recognised by monetary economists (the first being most apparent in a relatively open economy in which the exchange rate impacts on the prices of importables and exportables). The fourth channel relies on balance sheet effects, or bank lending effects initiated by interest rate changes (see, for instance, Mishkin, 1996 and Claus and Smith, 1999). In the case of a rise in interest rates initiated by monetary policy, the balance sheet channel 
works through a reduction in firm or household balance sheet strength as equity declines in the face of rising interest rates. This causes credit margins to expand and investment (including housing investment) to decline. The bank lending channel works through a weakening in banks' ability to lend in a setting with imperfect substitutability between bank credit and other forms of credit.

The credit channel is downplayed by Svensson, who subsumes it into the second channel. In some circumstances this may be justified, although Mishkin stresses that the credit channel primarily reflects a nominal (rather than real) interest rate channel to aggregate demand. It is important to follow through the implications of this difference. If, for instance, a supply shock causes inflation and inflation expectations to rise, interest rates must rise by more than the rise in inflation expectations to have a downward impact on aggregate demand (and thence on inflation) via the real interest rate channel. Nominal interest rates may not have to rise to the same extent to have a downward aggregate demand impact via credit effects. Explicit consideration of the credit channel may also be relevant if, as considered later by Svensson (and in this critique), there is conflict between the objectives of price stability and financial stability.

A fifth channel - wealth effects caused by asset price changes (other than exchange rate changes) - is not mentioned in the review, but is also now generally recognised as a potentially potent monetary policy transmission channel (Mishkin, 1996; Claus and Smith, 1999). In this case, given that the asset price changes under consideration are generally driven by interest rate changes, they can in part be subsumed under the second of Svensson's stated transmission mechanisms.

The second, third and fourth channels (plus the wealth channel) all impact on aggregate demand. Svensson notes that aggregate demand, in turn, impacts on inflation. Thus he outlines three key ways in which monetary policy impacts on inflation:

- $\quad$ aggregate demand channel to domestic inflation;

- production-cost channel to domestic inflation; and

- expectations channel to domestic inflation.

The second of these includes the direct exchange rate effect as well as impacts on the setting of wages and other production costs caused by changes in interest rates. The third, which gains some importance in Svensson's schema, stems from individual forward-looking wage and price setters being influenced by their expectations of future generalised inflation (for a survey of recent literature relating to this approach see Clarida, Gali and Gertler, 1999).

Importantly, these three channels, as well as those linking interest rate changes to aggregate demand, operate with different lags and potency. The most immediate is the direct exchange rate channel (although its speed and strength depends on the 'pass-through coefficient', which in turn depends on the state of the cycle and degree of competition). Effects which come about through changing aggregate demand, and hence the output gap, tend to be longer term (normally 
with a lag of at least a year). This makes it nearly impossible to operate monetary policy mechanistically. This has implications - discussed by Svensson and others such as Stevens (1998) - for mechanistic use of an MCI. It may also have implications - which Svensson does not discuss - for the use of direct exchange rate intervention as an adjunct to other monetary policy interventions. This point is highlighted further below.

While Svensson adopts the standard neo-Keynesian view that monetary policy affects real variables in the short-term as a result of price stickiness, he also maintains the conventional position that monetary policy is neutral with respect to the long-run level and growth rate of real output. Thus while a short-term tradeoff may exist, there is no long-term trade-off between price stability and the level or growth of output.

However, in keeping with Clarida et al and with his own earlier work, Svensson outlines a trade-off between variability in inflation and variability in output (around its potential level). Briefly, if the monetary authorities attempt to implement strict price stability in the face of cost shocks, they will have to vary interest rates and the exchange rate substantially, so causing considerable volatility in output (especially in traded goods output). Correspondingly, if they try to stabilise output in the face of such shocks, they will have to be prepared to experience considerable inflation variability. This observation leads Svensson to the issue of appropriate specification of monetary policy goals.

\section{Monetary Policy Goals}

From the preceding analysis, Svensson argues that long-run output growth cannot constitute a sensible goal for monetary policy, which instead is best targeted to serve a 'nominal anchor' role - that is to achieve long run price stability. Inflation targeting (designed to achieve low or zero inflation) is thereby appropriate, as indicated by the earlier quotation from the Review. However Svensson's analysis also demonstrates that strict or short-term inflation targeting is not generally warranted. This has major implications for the specification of monetary policy targets.

Figure 0.1 of the Review (reproduced as Figure 1 below) depicts a trade-off between output-gap variability and inflation variability. As Clarida et al. demonstrate, such a trade-off occurs principally in the face of supply shocks. For instance, a negative supply shock (for example, an intermediate import price increase) may cause output to contract while simultaneously raising inflation. An anti-inflationary monetary policy response in this circumstance will aggravate the shock's effect on output while reducing the impact on inflation. Similarly, a central bank aiming to stabilise near-term inflation will respond with an expansionary monetary policy to a positive supply shock. In contrast, a negative (positive) demand shock requires an expansionary (contractionary) monetary policy response that helps to stabilise both output and inflation. Thus the trade-off is less likely to be applicable when demand shocks occur. 
In Figure 1 (in the face of supply shocks), at one extreme, strict inflation targeting (SIT) yields the minimal feasible variability in inflation, but at the cost of high output variability. At the other extreme, strict output targeting (SOT) minimises volatility in output but with ever increasing variability in inflation. Flexible inflation targeting (FIT) represents a more moderate version of inflation targeting than does SIT. It is consistent with long run targeting of price stability within a framework that does not require a particular inflation target to be met at all times. Svensson (1997) has argued elsewhere that the New Zealand framework embodies a FIT approach and, as discussed in the Review, the RBNZ has moved even further towards flexibility in its implementation of inflation targeting since that paper was published.

Figure 1: The tradeoff between inflation variability and output-gap variability

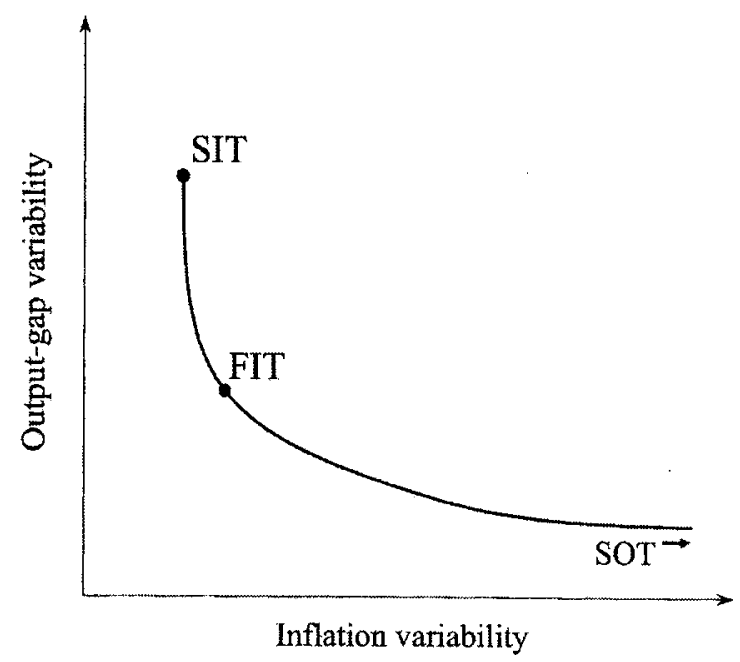

Source: Svensson (2001:Figure 0.1)

The choice of where one should be on the curve is a matter of policy-maker preference. In New Zealand, this is implicitly — or explicitly — spelt out through the Policy Targets Agreement (PTA) signed by the Minister of Finance and the Reserve Bank Governor. However Svensson points to a dynamic issue that may affect the choice and, to this, another country-specific angle can be added.

The dynamic angle relates to the credibility of monetary policy. Svensson considers a country (like New Zealand) that begins with a history of prolonged high inflation and hence high expectations of future inflation. Further, he assumes that inflation expectations will remain high until a central bank establishes a track record of reining in inflation on a sustained basis. A credible central bank may face the trade-off line depicted in Figure 1, while a less credible bank faces a less favourable trade-off line to the north-east of that depicted. A central bank may 
then seek to establish credibility by adopting a strict inflation targeting approach at a point to the east or north-east of the marked SIT. As its credibility in controlling inflation increases, the entire curve shifts downwards and to the left, presenting a more favourable trade-off for future policy-makers. At a point where credibility has been established, the central bank may shift to the marked FIT point which exhibits both lower output-gap variability and lower inflation variability than at the initial position. Without the initial fastidiousness in fighting inflation, no such beneficial gain on both fronts could have been achieved.

This analysis is a reasonable description of the New Zealand experience. Initially, the RBNZ adopted a fairly strict approach to inflation targeting (although never at the extreme SIT point). It did so by placing emphasis on the direct exchange rate channel to contain near-term inflation, targeting inflation 6 to 24 months ahead (Grimes and Wong, 1994:180; Grimes, 1996: 260). As inflation fell and credibility rose, the degree of flexibility that the Reserve Bank was prepared to tolerate around the inflation target mid-point expanded. Grimes (2000) notes that this development was anticipated at the time inflation targeting first began, consistent with the Svensson analysis.

There is one political economy aspect which Svensson does not discuss: If a point at or close to SIT is chosen initially, with resulting high output variability, confidence in the longevity of the monetary policy framework itself may be undermined leading to an expectation that the framework will be replaced by one which places greater emphasis on output stability (or output growth), leading to expectations of higher inflation and a rightward shift in the trade-off curve. Arguably, given early criticisms of the Reserve Bank's tight policy (see, especially, Whitwell, 1987) this expectation may have been prevalent, at least through the early years of the new framework, causing the RBNZ to operate along an unfavourable trade-off curve.

The country-specific angle is touched on by Svensson (2001) but can be developed further. He comments (p. 18) that there will always be some variability in both inflation and the output gap, but that the variability is likely to be substantial for small, open, less diversified and commodity-dependent economies like New Zealand and Australia. Developing this point, imagine two countries with identical policy-maker preferences concerning variability in output and inflation, but where the small country is assumed to face a trade-off curve to the north-east of that of the larger country. Given identical preferences and the assumption that both forms of variability are 'bads', the small country will choose to have both higher output-gap variability and higher inflation variability than the larger country. This observation is important when making cross-country comparisons of performance in terms of volatility of outcomes. Future research could examine the performance over time of a range of countries, given the macro-economic shocks which they face, to infer the position of the curve (reflecting credibility) and the position on the curve (reflecting policy-maker preferences). 


\section{Monetary Policy Recommendations}

The Review made observations and recommendations pertaining to each of the six TORs. In this section we discuss the recommendations pertaining to the five TORs which relate to monetary policy per se (thus excluding TOR 4, dealing principally with the monetary policy decision-making process, which is discussed in the next section).

In discussing the management of monetary policy in pursuit of the inflation target (TOR 1), Svensson discusses what he views as relatively minor but ex ante understandable policy 'mistakes' in the pre-MCI period. In particular, he notes a period of excessive easing in 1992 and 1993 . He presents a graph of the 90 day interest rate and the trade-weighted exchange rate (TWI) over 1991-2000 to illustrate the cycles in monetary policy settings over this period (although relativities of New Zealand interest rates with international rates, especially in Australia and the United States, would also have been instructive). It would also have been helpful to have presented this graph over a longer setting dating back to the float of the exchange rate in 1985, since the cycles at the start of the 1990s can be shown to have had their genesis in settings as early as the immediate post-float period, which arguably engendered excessive tightness. With the benefit of hindsight it is apparent that this period of initial tightness was followed by a period of excessive easing, followed by excessive tightening again in the late 1980s and early 1990s, after which came the episode of excessive easing to which Svensson refers.

By adopting a longer time horizon, Svensson may have been forced to investigate more deeply whether there has been a systemic problem with the New Zealand monetary policy framework (before and after the passage of the RBNZ Act) that has caused an over-reaction to perceived overly tight or loose conditions. In particular, the cycle of excessive easing followed by excessive tightening over much of the fifteen year period 1985-2000 may imply that monetary conditions have had to be altered too drastically in the face of current imbalances. Possibly, this has been because of the nature of the inflation target which emphasises control of CPI inflation over annual time intervals. If the time interval for the accountability framework were longer (possibly the course of the cycle as in Australia) there may have been less need to engender such sharp swings in interest rates and the exchange rate as has occurred in New Zealand. Investigation of this issue, together with the reasons for the faster than expected disinflation over 19901992, is, to a large extent, downplayed in the Svensson report.

Svensson finds considerable fault with the adoption and application of the MCI over the June 1997 to March 1999 period. Over this period the RBNZ adopted as its main signalling tool (and intermediate target) a weighted average of the 90 day interest rate and the TWI with a fixed weight of 0.5 on the exchange rate. In explaining the system (Reserve Bank of New Zealand, 1998), the Reserve Bank emphasised that the relative weightings of the two indicators were not precise and that the correct ratio may well vary over the course of the business cycle. Hence the MCI should not be viewed mechanistically; rather, it was a 
means of signalling the Bank's view of the appropriate stance of monetary policy without taking a specific view on either interest rates or the exchange rate. In practice, however, the Bank's subsequent use of the MCI (at least in the public arena) gave the impression of a mechanistic application of a fixed weight index.

Relating his comments back to his earlier discussion of the variable lags inherent in the range of transmission mechanisms, Svensson analyses why a relatively mechanistic application of an MCI constructed in this way can be an unreliable guide for monetary policy. This is particularly the case when unusual shocks - such as the Asian financial crisis that occurred during this time - arise.

Following the onset of the Asian crisis, New Zealand interest rates rose despite the recognised depressed demand for New Zealand exports. This policy response was occasioned by use of the MCI in face of a substantial TWI fall. The quarterly average 90 day interest rate rose by 81 basis points between the second and third quarters of 1997 and peaked at 195 basis points above its pre-crisis level one year after the crisis. In conjunction with a number of other factors (including drought), this contributed to a sharp slowing in the New Zealand economy. By contrast, the RBA reduced short term interest rates through explicit monetary policy actions. The Australian quarterly average 90 day interest rate fell by 80 basis points between the second and third quarters of 1997, and remained at approximately this new level for the succeeding two years. This policy response helped to cushion the Australian economy against the adverse external shock. ${ }^{1}$

With the adoption of a narrow corridor for the overnight cash rate as monetary policy instrument in 1999, New Zealand adopted a conventional monetary policy implementation approach. Svensson finds both this approach, and its subsequent application, to be in line with best practice. This approach is in line with that of Australia, which had adopted it much earlier. By implication, therefore, Svensson finds that the monetary policy implementation in Australia is in line with best international central bank practice.

Svensson also analyses the specification of the inflation target, currently based on the maintenance of inflation within a target band of 0-3 per cent per annum. Reflecting earlier RBNZ internal discussions, he questions whether this range should be interpreted as a 'range of indifference' for the Reserve Bank or as a point target of 1.5 per cent (the mid-point of the target band) and, if the latter, how hard-edged the limits of the range should be. He judges 1.5 per cent to be a reasonable mid-point for the target: 'I am not aware of any strong evidence to suggest that 1.5 percent would not be an appropriate level' (p. 44). Reflecting his theoretical advocacy of flexible inflation targeting, Svensson prefers a point policy target which ideally would read: 'the policy target shall be 12-monthly increases in the CPI of 1.5 percent over the medium term' (p. 43) with 0 per cent and 3 per cent being interpreted as soft-edged limits for the target range. This differs from

1 While the short-term interest rate responses to the crisis were quite different between New Zealand and Australia, recent research by Ellis and Lewis (2001) suggests that other financial market price reactions - measured by share prices, 10 year bond rates and bilateral exchange rates versus the United States dollar — were similar. 
the existing range target with specific (although not necessarily hard-edged) boundaries.

Implicit within Svensson's recommendation, given that it differs from the current specification, is a call for even softer-edged boundaries to the 0-3 per cent target than at present, but with a more explicit point target. However, he pays less attention to an alternative specification that emphasises a point target over a longer period. As discussed above, the annual focus in New Zealand may have caused problems for inflation targeting so that a longer time interval - possibly the length of the economic cycle as in Australia - may be a preferable way of specifying the target, especially once central bank credibility had been established.

In his response to the Review, the Minister of Finance chose not to adopt the change mooted by Svensson. However, since this is not a legislative matter, it is open for a future Minister and Governor to agree to a policy target in line with Svensson's specification.

Svensson's recommendations in this respect can be applied to the Australian situation. The Australian target - an average inflation rate of 2-3 per cent p. a. over the course of the cycle - is neither a point target nor a range specific to a particular time period. It embodies the soft-edged properties desired by Svensson but lacks an explicit point target to anchor expectations. To the extent that the mid-point of the target can be viewed as an expectations anchor, one might expect Svensson to decide that this is slightly on the high side (given his view of the appropriateness of a figure nearer 1.5 per cent as a point target). Thus a reexamination of the level of the Australian inflation target (perhaps to a point target of 2 per cent per annum to maintain consistency with the lower end of the existing range) may be appropriate. However, given the earlier discussion, the specification of the Australian target as being an average over the course of the cycle may lead to less volatility in monetary policy outcomes and to better long term economic performance than has New Zealand's annual specification. This remains a topic for further research.

Svensson's conclusions with regard to the instruments of monetary policy (TOR 2) have been indicated above: the use of the overnight cash rate as principal monetary policy instrument is regarded as consistent with best international practice. The MCI is seen to have been a 'significant departure' from best practice. Svensson finds no benefit in adopting supplementary monetary policy tools such as reserve ratios, capital controls, other tax or regulatory interventions and foreign exchange interventions. He finds such tools to be either redundant (for example, reserve ratios operate also through the short-term interest rate channel) or inefficient (for example, administrative credit controls distort lending patterns).

One finding relevant to Australia, based on 'much research and practical experience', is Svensson's view that sterilised foreign exchange interventions 'normally have only small and short-lived effects'. He notes that they can be effective if viewed as signals of monetary policy intentions, but there are other more transparent ways of sending such signals. Thus he considers there is "no reason why a transparent inflation-targeter should undertake foreign-exchange 
interventions' (Svensson, 2001:48). The Reserve Bank of Australia, which periodically still undertakes such interventions (Reserve Bank of Australia, 2001), would thus be seen by Svensson to be employing a redundant and potentially suboptimal instrument. One possible reason for retention of this instrument could be that Australia's inflation target is not quite so transparent as that of New Zealand.

However there are other reasons which Svensson does not discuss but which, given the variety of transmission mechanisms that he outlines, could provide grounds for retention of foreign exchange intervention. Consider, for instance, an immigration surge which causes a sharp increase in house prices and in consumer prices more generally. The response of a CPI inflation targeting central bank will generally be to raise short term interest rates to place downward pressure on inflation through the various channels already outlined.

If, as suggested by Svensson, the direct exchange rate effect is of primary importance over the initial year after the tightening, the bulk of adjustment will take place through traded goods price changes and through a downward shift in activity in the traded goods sector, rather than through a reduction in domestic demand (in which the inflationary surge initially began). A central bank that is not constrained to target annual inflation, but which targets inflation over the course of the cycle, may wish to spread the transmission mechanisms over a number of channels. At the same time as raising interest rates, the central bank may then undertake foreign exchange intervention to reduce near-term appreciation of the exchange rate, leaving the longer term domestic demand channels to be the more important conduits of the anti-inflationary policy.

For example, consider the policy-induced reduction in domestic short-term interest rates in Australia over the first half of 2001 in response to the weakness of the international economy. Following these reductions, the Australian dollar came under downward pressure and, at times, there was a policy response: 'The Bank has intervened in the market from time to time to provide support when market sentiment seemed to be unreasonably bearish' (Reserve Bank of Australia, 2001:2). Thus, despite a desire to cushion the domestic economy from the international downturn, the RBA chose to limit the exchange rate's downward path, so placing greater relative emphasis on the interest rate transmission channel.

This practice is not necessarily inconsistent with Svensson's view that foreign exchange intervention has only short term effects. Indeed, the purpose of such interventions is to have only short lived effects, mitigating the temporary impacts on the traded goods sector of a monetary tightening (or, conversely, the excessively favourable effects on the sector of a monetary loosening). In a world incorporating significant hysteresis effects, such short term smoothing may be a material contributor to longer term beneficial economic outcomes.

Svensson (TOR 3) comments that some important data (for example, the CPI and industrial production) are available only at quarterly frequencies and recommends that Statistics New Zealand make these available at monthly frequency. In subsequent comments, the Reserve Bank of New Zealand, Treasury and the Minister of Finance all downplay the relevance of this issue to a small, commodity-dependent economy such as New Zealand (or Australia). They note 
that monthly data for such a country would be highly volatile and produce little in the way of signal relative to noise.

One other finding in this area is more relevant. Svensson notes that the Reserve Bank and a number of other (mainly private sector) agencies collect data on inflation expectations, but none do so systematically. Given the importance that Svensson places on expectations in the transmission mechanism and as an indicator of policy credibility, he recommends that the Reserve Bank commission Statistics New Zealand to collect and publish series for medium and long-term inflation expectations.

In the Australian context, the Reserve Bank of Australia (2001) quotes inflation expectations derived from surveys conducted by the Melbourne Institute, the Australian Centre for Industrial Relations Research and Training, the National Australia Bank, and an informal survey of financial economists conducted by the RBA itself, but again there is no official source for inflation expectations data. As for the New Zealand situation, there is a case for the RBA to commission the Australian Bureau of Statistics to undertake a formal expectations survey.

With regard to monetary-fiscal policy co-ordination (TOR 5), Svensson is satisfied with the New Zealand set-up whereby the Reserve Bank Act specifies a clear role for monetary policy and the Fiscal Responsibility Act produces clarity with regard to overall fiscal policy. The type of co-ordination seen in Australia (in which the Secretary of the Treasury sits on the RBA Board and officials from the RBA and Treasury meet to discuss policy) is not seen to be necessary or particularly useful once these structures are in place.

More contentiously, Svensson (2001) also sees little problem with coordination between monetary policy and policies designed to prevent financial instability. In particular he states (p. 60):

In times of financial crisis, there may sometimes be a conflict between price stability and financial stability. A typical conflict situation is when the appropriate monetary policy calls for a monetary policy tightening, but such a tightening might further damage already weak balance sheets in the financial sector and possibly trigger a collapse of the financial and payment system. Such a situation would, however, typically arise in a situation with already high or rapidly rising inflation.

He sees such a situation as unlikely. However, history demonstrates a number of examples of such policy incompatibility. New Zealand, and to a lesser extent Australia, faced a situation in the late 1980s where monetary policy needed to remain tight to reduce inflation but where financial stability may have demanded greater easing. Japan's prolonged financial crisis calls for monetary easing, which currently is consistent with the need to fight deflation, but which potentially could become inconsistent with a subsequent requirement to contain a material rise in inflation.

Monetary policy communication (TOR 6) is an important art for central bankers to master. Svensson finds little to criticise in the Reserve Bank in this 
regard and is particularly complimentary about the Bank's transparency in its communications. A key feature of this transparency is the Bank's quarterly publication of three-year forward projections for the crucial macroeconomic and financial variables. These detailed projections, in his view, 'give the Reserve Bank an edge relative to other inflation-targeting central banks' (p. 62).

The key issue to which he points is how best to communicate uncertainty of published central bank projections to the public. He notes the importance of emphasising the conditional nature of projections (based on certain assumptions). $\mathrm{He}$ also points to the usefulness of displaying widening confidence intervals over time in relation to projected variables. He does not favour a recent 'unsophisticated' RBNZ practice of rounding projected numbers to the nearest half percent to indicate uncertainty.

These observations regarding projections are relevant also to the Reserve Bank of Australia. The RBA provides very little forecast detail relative to that provided by the RBNZ, and what is provided is relatively vague. Consider, for instance, the RBA's Statement on Monetary Policy, in which virtually the only forecast pertaining to any macro variable is expressed as: 'On balance, the Bank's expectation is that, net of taxes and petrol prices, underlying inflation will remain around the top of the 2 to 3 per cent medium-term target band for the rest of 2001, before easing gradually in 2002 ... CPI inflation is likely to be a little lower than this.' (Reserve Bank of Australia 2001:60). No forecasts for the real economy or for any financial variable are provided. The lack of forward-looking detail provided within the RBA Statement makes the RBA's approach considerably less transparent than that of the RBNZ. The RBA may accordingly wish to consider Svensson's recommendations on this matter.

\section{Decision-Making and Accountability Recommendations}

Svensson devotes a considerable proportion of the Review to discussing TOR 4 which covers the monetary policy decision-making process, governance issues and accountability structures. This takes him to organisation theory. In a recent paper, Williamson (2001) recommends that economists pay much more attention to the organisation theory literature in examining suitable governance and accountability structures. Such analyses need to recognise a multitude of factors affecting incentives of individual agents that economists frequently ignore. Unlike his treatment of monetary policy, however, Svensson does not outline a framework for governance and accountability investigations, relying instead on intuition and international precedent. This omission leaves his findings plausible, but no more plausible than other recommendations based on different intuition or precedent.

The key issue under examination is whether there should be a single decisionmaker (as is the Reserve Bank Governor in New Zealand) or a committee (as with the Reserve Bank Board in Australia) for monetary policy decisions. Svensson notes that the latter is more normal, although Canada is another country where legislation stipulates a single decision-maker. In practice, however, the current Bank of Canada Governor has agreed to be bound by the decision of the 
Governing Council comprising the Governor and five Deputy Governors (Archibald, 2001). If a committee structure is chosen, a separate issue is whether the committee should comprise solely monetary policy experts (as with the Bank of England Monetary Policy Committee) or should also include non-expert members (as with the Reserve Bank of Australia Board).

Svensson lists some advantages of a single decision-maker: strong accountability, coherence in decision-making, and clarity in communications. Disadvantages include: dependence on the qualities, knowledge and experience of a single individual, and issues of legitimacy arising from vesting so much power and responsibility in the hands of a single individual.

Svensson notes that the term of the current Governor (Dr Don Brash) has not been subject to the disadvantages listed, in his view because of the Governor's personal qualities, including openness and willingness to take advice. However, the existing structure may not work as well with an alternative appointment. This leads Svensson to favour a committee structure. He notes however, that 'the wrong committee' could result in a worse outcome than would reliance on a single individual. Any committee structure would need to maintain sufficient accountability and coherence in decision-making and communications to be preferable to the single decision-maker model.

With this caveat in mind, in designing a Monetary Policy Committee (MPC) structure, Svensson recommends that this decision-making committee (as opposed to a monitoring committee) should consist solely of people with monetary policy expertise. Monetary policy targets have already been set (by the Policy Targets Agreement in New Zealand), thus making monetary decision-making primarily a technical rather than political task. Consequently, Svensson(2001:52) concludes:

This also implies that appointments to an MPC with a purpose of sectoral, political or other special-interest representation would be mistaken. Not only is it unnecessary, but it would bring special-interest conflicts into the committee, cause deadlocks or risk policy serving special interests rather than the country as a whole.

Further, because of what he perceives as the limited supply of monetary policy experts outside the Reserve Bank who do not have a conflict of interest (for example, by virtue of working within the financial sector), Svensson recommends that an internal MPC be adopted. He proposes a committee comprising the Governor, two Deputy Governors and two nominated senior Reserve Bank staff, with votes and non-attributed minutes published with a two to three week lag.

Significantly, Svensson (2001:53) recommends that this MPC take responsibility for all monetary policy decisions, but that: 'In all other areas, the Governor would remain the single decision-maker of the Bank'. This recommendation creates a number of issues.

Firstly, what is defined as monetary policy? In the financial crisis example discussed earlier, is the interest rate decision a monetary policy decision or a financial stability decision? If it is the latter, Svensson's recommendation points to 
the Governor alone making the decision; but the MPC might object that the decision is inappropriate for monetary policy purposes. Some form of resolution is required, but is not forthcoming in the report. Secondly, the weaknesses of single decision-making pointed to by Svensson are as relevant for non-monetary decisions as for monetary decisions. If a single decision-maker is not thought appropriate for the monetary policy function, why should it be appropriate for other central bank functions? Svensson does not answer this question.

These quandaries highlight the lack of a framework within the Review for analysing organisational issues. There is no analysis, for instance, of the suitability for central banks of the standard corporate model of a decision-making Chief Executive, subject to Board monitoring (essentially the New Zealand Reserve Bank model). Nor is there analysis of the nature of public sector reform in New Zealand under the Public Finance Act that created accountable Chief Executives of government departments. Without doubt, these issues are difficult to analyse and there is unlikely to be a single 'right' structure, but these difficulties make a framework for analysis more, rather than less, necessary.

Given his approach, Svensson ranks a number of structures in terms of his judgement as to their suitability for monetary policy decision-making from best to worst as follows:

- $\quad$ MPC comprising solely internal members;

- $\quad$ MPC with expert external members;

- $\quad$ Expert Governor as single decision-maker;

- MPC with some expert and some non-expert external members (the more non-expert members, the worse the structure).

Thus, while advising against retention of the existing New Zealand decisionmaking model, Svensson is even more critical of the current formal Reserve Bank of Australia decision-making structure largely comprising a non-expert Board of Directors, many chosen on the basis of sectoral interests. This had been the decision-making structure of the Reserve Bank of New Zealand prior to the 1989 Act. Given his criticisms of the inclusion of non-expert decision-making directors, especially once monetary policy goals are clearly specified (as they now are in Australia), Australia may wish to revisit the decision-making structures of the RBA, to focus decision-making more formally on monetary policy experts either within the Bank's staff or within an expert sub-committee of the Board.

A further important accountability recommendation by Svensson relates to the nature of Board monitoring. In New Zealand, as in many other central banks, the Governor is both the Chief Executive and Chairman of the Board of Directors. Svensson finds this problematic for Board monitoring, especially in the case of a single decision-maker, but also with the proposed MPC format. He favours a Board made up solely of non-executive directors (or as a possible compromise, with the Governor as a non-voting member) - Deputy Governors would not be Board members. To protect against political intrusion, the Chair would be elected by the (non-executive) directors. This contrast to the current New Zealand and 
Australian structures where the Governor chairs the Board of Directors. Further, the non-executive directors would be required to contribute an independent report on monetary policy within the Bank's Annual Report. This structure, albeit with the inclusion of the Chief Executive as a director, is closer to the standard corporate model. However, this again questions why a single decision-maker supplemented by a monitoring Board, is not favoured by Svensson.

Responses to the Svensson recommendations have generally favoured the move to an independent chair and the adoption of a separate non-executive directors' report, but have rejected a committee decision-making structure. Interestingly, the current Non-Executive Directors' Committee favours retention of the Governor as single decision-maker for all Reserve Bank decisions, but favours an independent chair chosen by the non-executive directors. They also favour retaining both the Governor and the Deputy Governors as directors. Retention of the Chief Executive on the Board is regarded by the non-executive directors as 'usual corporate governance practice'. Retention of the Deputy Governors is favoured in order that non-executive directors can obtain greater insights into policy discussions, the Governor's management practices and potential successors to the Governor (noting that the Act requires the Board to nominate a Governor to the Minister of Finance). Consistent with this view, both the Deputy Governor and the Governor are members of the RBA Board.

The Minister of Finance's response to the recommendations under this TOR echoed the non-executive directors in most respects: retention of the Governor as single decision-maker and board member; and changing the Act to introduce a non-executive chair elected by the non-executive directors. It differed from their recommendation by deciding to remove Deputy Governors as directors. As an additional response which partly acknowledges that wider input into monetary policy is desirable, the Reserve Bank subsequently appointed two part-time external advisers 'chosen for their broad knowledge of the New Zealand economy' who 'will be expected to participate in the Bank's internal decisions in the monetary policy process and ... to provide the Governor with advice in relation to OCR decisions' (Archibald, 2001). This response by the Bank, however, appears to be at odds with Svensson's recommendation which was designed to increase the role of monetary policy experts (rather than individuals with a 'broad knowledge' of the economy) in monetary policy decision-making.

The decisions of both the Minister and the Bank in relation to this TOR unlike the monetary policy areas that echoed the Review's recommendations were considerably at odds with the Svensson report. The Minister's decisions reflected more closely the form of the 1989 Act that was partly informed by New Zealand's public sector reforms (especially the Public Finance Act) on personal accountability of the Chief Executive of government departments. The key new feature added to the accountability framework will be the appointment of a nonexecutive Board Chair chosen by the non-executive directors. This feature, which is in keeping with 'best practice' corporate governance, combined with the newly adopted non-executive directors' report within the Bank's Annual Report, could be considered as potential enhancements by the RBA. 


\section{Conclusion}

Ten years after its inception, the Reserve Bank of New Zealand Act 1989 is largely intact after the Svensson review and the Minister of Finance's responses. The single price stability target for monetary policy, the Governor as single decision-maker and a monitoring (non decision-making) Board of Directors have all been upheld, albeit with the second of these at odds with Svensson's recommendation. However, an important accountability change will be made to the Board structure, with non-executive directors electing an independent Chair.

In terms of monetary policy implementation, the current practice of setting an OCR in response to a forward-looking inflation projection relative to the $0-3$ per cent target is retained. The $0-3$ per cent range target is also maintained, although Svensson had a preference to convert it to a point target of 1.5 per cent plus or minus 1.5 per cent. In effect, however, there is practical agreement that 1.5 per cent annual inflation is the central target for monetary policy with soft edges around the $0-3$ per cent range.

If the same review were applied to the current Australian arrangements, one would expect approval of the monetary policy implementation regime based on a short-term interest rate. The soft-edged nature of the inflation target would be regarded as reasonable, although possibly a little vaguely expressed and the central target of 2.5 per cent may be regarded as somewhat higher than necessary. Further, an improvement in transparency could be sought through the provision of more detailed forecasts for macroeconomic and financial variables. The most notable recommendations are likely to pertain to governance and accountability structures. In particular, the decision-making structure involving a board of largely non-expert outsiders would be regarded as close to the worst available arrangement. In addition, as with the New Zealand recommendations, a nonexecutive Chair for the Board would be recommended, with the Board having a monitoring, rather than decision-making, role.

In New Zealand, legislative changes to effect the necessary changes following the Review are likely in the near future. Across the Tasman, close analysis of the Svensson report, and its implications for Australia, could also establish a need for legislative changes to effect improved governance and accountability procedures for what is one of the most important economic institutions in the modern economy.

\section{References}

Archibald, J. (2001), 'Independent Review of the Operation of Monetary Policy: Final Outcomes', Reserve Bank of New Zealand Bulletin 64(3):4-14, Sept.

Clarida, R., J. Gali and M. Gertler (1999), 'The Science of Monetary Policy: A New Keynesian Perspective', Journal of Economic Literature 37:1661-1707, Dec.

Claus, I. and C. Smith (1999), 'Financial Intermediation and the Monetary Transmission Mechanism', Reserve Bank of New Zealand Bulletin 62(4):4-16, Dec. 
Ellis, L. and E. Lewis (2001), 'The Response of Financial Markets in Australia and New Zealand to News About the Asian Crisis', Research Discussion Paper 2001-03, Reserve Bank of Australia, Sydney.

Grimes, A. (1996), 'Monetary Policy', pp. 247-278 in B. Silverstone, A. Bollard and R Lattimore (eds) A Study of Economic Reform: The Case of New Zealand, Contributions to Economic Analysis 236, North-Holland, Amsterdam.

Grimes, A. (2000), 'Submission to the Independent Review of the Operation of Monetary Policy', available on official website: www.monpolreview.govt.nz

Grimes, A. and J. Wong (1994), 'The Role of the Exchange Rate in New Zealand Monetary Policy', pp. 176-197 in R. Glick and M. Hutchison (eds) Exchange Rate Policy and Interdependence: Perspectives from the Pacific Basin, Cambridge University Press, Cambridge.

Mishkin, F. (1996), 'The Channels of Monetary Transmission: Lessons for Monetary Policy’, NBER Working Paper 5464, Cambridge, MA.

Reserve Bank of Australia (2001), 'Statement on Monetary Policy', Sydney, August, available at: www.rba.gov.au.

Reserve Bank of New Zealand (1998), 'Monetary Policy Statement', Wellington, May.

Stevens, G. (1998), 'Pitfalls in the Use of Monetary Conditions Indexes', Reserve Bank of Australia Bulletin August:34-43.

Svensson, L. (1997), 'Inflation Targeting in an Open Economy: Strict or Flexible Inflation Targeting?', Public Lecture, Victoria University of Wellington, November; reprinted in Victoria Economic Commentaries March (1998):15-1.

Svensson, L. (1999), 'Inflation Targeting as a Monetary Policy Rule', Journal of Monetary Economics 43:607-654.

Svensson, L. (2000), 'Open-Economy Inflation Targeting', Journal of International Economics 50:155-183.

Svensson, L. (2001), Independent Review of the Operation of Monetary Policy in New Zealand: Report to the Minister of Finance, Wellington.

Tinbergen, J. (1952), On the Theory of Economic Policy, North-Holland, Amsterdam.

Whitwell, J. (1987), 'Monetary Policy with a Deregulated Financial Sector' pp. 261-282 in A. Bollard and R. Buckle (eds) Economic Liberalisation in New Zealand, Allen \& Unwin, Wellington.

Williamson, O. (2001), 'Public Policy Analysis: Economics and Organisation Theory', IPS Policy Newsletter, May.

I wish to thank Graeme Wells for suggesting that I review the Svensson report and two anonymous referees for their comments on an earlier draft. I alone am responsible for the views expressed 